\title{
Tema: Udveksling og Pagt
}

I forbindelse med lektor, dr.theol. Ole Davidsens 60 års fødselsdag d. 20. september 2010 organiserede Kasper Bro Larsen og jeg - to af hans tidligere studerende - et symposium in honorem Ole Davidsen. Emnet var næsten givet på forhånd. Det skulle dreje sig om pagt og udveksling, som gennem det meste af Davidsens karriere har spillet en afgørende rolle i hans forskning og ikke mindre væsentlige formidlingsindsats - i skrift som i undervisning. Samtidig er der tale om et grundlæggende problemfelt inden for de religioner, man traditionelt betegner de monoteistiske; men diskussionen rækker videre, for man kan dårligt forestille sig religioner eller for den sags skyld fortællinger - religiøse eller ej - som ikke basalsemiotisk er organiseret ud fra kontraktuelle strukturer knyttet til udveksling og pagt: pagt som en særlig semantisk og historisk krystallisering af udvekslingsstrukturen. Ja, man kan med rimelighed hævde, at kontraktuelle strukturer udgør omdrejningspunktet for al menneskelig kommunikation og interaktion, hvad enten man forestiller sig, at det er med guder eller mennesker. Symposiet havde bidragydere fra de to institutioner, som har udgjort kernen i Davidsens karriere, Afdeling for Gammel og $\mathrm{Ny}$ Testamente og Afdeling for Religionsvidenskab ved Aarhus Universitet. Denne institutionelle sammenstilling er vel også det nærmeste, man kommer den en gang unge Davidsens ønske om religiologi som en semiotisk og kulturvidenskabeligt funderet hybrid mellem religionsvidenskab og teologi. At det er forskere ved de to institutioner, der bidrog ved symposiet, er også en honorering af Davidsens ønske om en humanistisk funderet teologi, der har skærpet sansen for Bultmanns gamle pointe om en snæver sammenhæng mellem teologi og antropologi.

Davidsens første internationalt publicerede artikel drejede sig om pagt i Det Gamle Testamente (Linguistica Biblica 48, 1980), men temaet har uophørligt fulgt ham siden. Således også i disputatsen, The Narrative Jesus: a Semiotic Reading of Mark's Gospel (1993), som det næppe er en tilsnigelse at betegne som en i semiotisk forstand pagtsteologisk læsning af Markusevangeliet. Afhandlingen var internationalt et metodisk nybrud og et markant udtryk for, hvor langt man ad en fransk semiotisk-narratologisk vej kan komme i analysen af tidlige kristne tekster. Udveksling mellem menneske og gud har imidlertid ikke kun ført Davidsen til studiet af pagt i snæver forstand. Han har som få andre i dansk fagteologi haft sans for tekstualiseringens betydning for italesættelse af forbindelsen mellem gud og menneske. Derfor har han også bidraget med væsentlige studier af dansk salmetradition, deiksis i religiøse tekster, og undersøgelser af intertekstualitet 
som semiotisk fænomen. Dertil kommer en vigtig indsats i teologisk forskningsformidling. I de sidste år har Davidsen også føjet en ny dimension til sin undervisning og forskning. Han har, inspireret af ægtefællen Hanne Davidsen med en diplomuddannelse i dramaturgi og pædagogik, for alvor fået øje for kroppens betydning i udvekslingen mellem gud og menneske. Det ser man i hans seneste arbejder.

Temanummerets bidrag spejler Davidsens interesser i udveksling og pagt. Hans J. Lundager Jensen skriver fra et gammeltestamentligt perspektiv om Abraham som høflighedens ridder. Jensen bruger antropologi til at blænde ned for overeksponeret teologi. Abraham som købmand og kapitalbesidder med forbindelser på tværs af sociale og etniske grænser er muligvis også en tavs kritik af en eksklusivitetsteologi fokuseret på Israel og dets grænser. Her ligger et religionshistorisk og teologisk residual parat til at tages op i en kritik af al eksklusivitetsteologi.

Den nu modne Davidsen skriver om fjendekærlighed og vennehad i Sletteprædikenen. Kærlighedsbuddet er måske nok socialt paradoksalt, men semantisk er det ikke uden ræson. Flankeret af barmhjertighedens og ondskabens rige, der begge, men på forskellig vis, er anarkistiske, står retfærdighedens rige, hvor nåde ikke går for ret. Davidsen viser gennem semiotisk analyse, hvordan barmhjertighedstanken overtrumfer de to andre riger, fordi fremme og bevarelse af liv ontologisk og moralsk har forrang for det onde, også når det legitimerer sig som retfærdighed.

I mit bidrag falder man tilbage i retfærdighedens rige. I en studie af 2 Korinterbrev gør jeg gældende, hvordan kollekten kalkeret som gavmildhed er udtryk for retorisk tvang fra Paulus' side. Den er i sidste instans et retorisk påtvunget offer, korinterne skal bringe som udtryk for deres accept af Paulus' budskab. Samtidig bruger jeg essayet til at sige noget om religion (inkl. kristendom) generelt. Som et stykke eksessiv kultur fungerer religion kulturstabiliserende.

Kasper Bro Larsen slutter de nytestamentlige bidrag med en teologisk tour de force, hvor han gør gældende, at en rumlig nærhedsteologi ligger bag nytestamentlig kristendom. Frelse og eskatologi i $\mathrm{Ny}$ Testamente har som mål at bringe mennesker og Gud nær hinanden. Her ligger kimen til en anderledes tænkt nytestamentlig teologi.

Som afslutning skriver Thomas Hofmann om pagter i Koranen. Han viser, hvordan pagtrelationer vedrører Gud og menneske, Muhammed og Gud, samt Muhammed og menneske, ligesom han argumenterer for, at pagt i den oprindelige betydning som 'binding' og 'sammenføjning' som metafor skal tages alvorligt. Også han viser sans for sammenhængen mellem krop og sprog, tale og legemlighed. 